Review article

\title{
Quality protein maize (QPM): Genetic basis and breeding perspective
}

\author{
Swapan K. Tripathy*, Dinesh M. Ithape, Manasmita Maharana and A. M. Prusty
}

Department of Agricultural Biotechnology, College of Agriculture, OUAT, Bhubaneswar, Odisha, India

*Corresponding Author: swapankumartripathy@gmail.com

[Accepted: 10 April 2017]

\begin{abstract}
Major fraction (60\%) of seed storage protein in maize is zein which determines the quality of food and feed. Zeins comprise four subfamilies e.g., $\alpha, \beta, \gamma$ and $\delta$ zeins. Among these, $\alpha$ - zeins are the major prolamin subunits in maize. $\alpha$-zeins are rich in glutamine, leucine and proline but, deficient in essential amino acids like lysine and tryptophan causing malnutrition. The opaque-2 (o2)-a natural recessive mutation in maize led to nearly double the lysine and tryptophan content in endosperm due to a decrease in the synthesis of zein proteins and increase in the other seed protein bound lysine and tryptophan. RNAi studies proved down regulation of $22 \mathrm{kD}$ zeins than the $19 \mathrm{kD}$ component as the biochemical basis of QPM phenotype. However, the opaque-2 mutation made the endosperm chalky and soft resulting damaged kernel while harvesting, poor germination, increased susceptibility to pest and diseases, inferior for food processing and in general reduced yield. Later, combining opaque-2 allele with its desirable genetic modifiers made it possible to breed QPM genotypes having hard kernel with high lysine and tryptophan content. Since, opaque-2 is a recessive mutation and endosperm specific, and biochemical analysis of lysine and tryptophan content is expensive; conventional backcross breeding alone is inefficient for the nutritional enrichment of maize. However, use of opaque-2 gene specific markers provided excellent opportunities for conversion of elite normal inbreds to homozygous o2/o2 forms through marker assisted selection (MAS). In India, Vivek QPM-9: a hybrid of two QPM introgression lines is being widely used for commercial cultivation.
\end{abstract}

Keywords: Quality protein maize (QPM) - Opaque-2 - Nutritional value - Introgression lines QPM hybrids.

[Cite as: Tripathy SK, Ithape DM, Maharana M \& Prusty AM (2017) Quality protein maize (QPM): Genetic basis and breeding perspective. Tropical Plant Research 4(1): 145-152]

\section{INTRODUCTION}

Maize is the queen of cereal crops with highest grain yield potential. Endosperm is the store house of seed storage proteins. Maize grains contain around $9 \%$ protein. The major fraction $(60 \%)$ of seed protein in maize is zeins (a prolamin group-alcohol soluble) (Leite et al. 1999) followed by glutelin (34\%), while albumin and globulin occur in traces ( $3 \%$ each). A balanced protein is required to assist body building process and therefore, amino acid balance seems to be a determining factor for quality of any food and feed. Daily protein requirement for average Indian adult is $52 \mathrm{gm}$ as against the availability of merely $26-30 \mathrm{gm}$ in the daily diet. To alleviate malnutrition, protein content can be increased to as high as $18 \%$ by increasing the prolamine (zein) fraction in maize endosperm (Dudley \& Lambert 1969), but unfortunately it consequently led to lysine and tryptophan deficiency. Many researchers around the globe have tried to address the problem using quality protein maize (QPM). In this pursuit, we focus on the genetic basis and prospects of quality protein maize for amino acid amelioration and enhancing the productivity of maize through the development of heterotic hybrids using elite QPM introgression lines.

\section{GENETIC BASIS}

Zein seed proteins are the products of multigene families (Lending \& Larkins 1989) and located within protein bodies on the rough endoplasmic reticulum (Larkins et al 1993). Each of the zein polypeptide is a product of a differential structural gene $(\mathrm{Zp})$. These $\mathrm{Zp}$ genes are simply inherited and are members of a large 
group of genes (upto 150). Zein is particularly rich in glutamine (21-26\%), leucine (20\%), proline (10\%) and alanine (10\%), but deficient in important essential amino acids e.g., lysine and tryptophan leading to protein malnutrition. $\alpha$ - zeins are the major prolamin subunits in maize, although other minor groups $(\beta-15 \mathrm{kD}, \gamma-16 \&$ $27 \mathrm{kD}$ and $\sigma-10 \mathrm{kD}$ zeins) (Coleman \& Larkins 1999, Leite et al. 1999) are also present in seeds. In normal maize, $\alpha$ - zeins consist of two major sub-classes e.g., $19 \mathrm{kD}$ and $22 \mathrm{kD}$ zeins. Polymorphism arises from the presence of multigene families. $\alpha$ and $\sigma$-zeins form the protein body core which is covered by peripheral $\beta$ and $\gamma$ - zeins (Lending et al. 1992, Esen \& Stetler 1992).

The discovery of opaque-2 (o2) natural mutants by Purdue university researchers paved the way for improving protein quality of maize endosperm protein (Mertz et al. 1964, Nelson et al. 1965). These mutants alter amino acid profile and composition of maize endosperm protein and result in two-fold tryptophan increase in the levels of lysine and tryptophan compared to normal maize. However, the pleiotropic effects of opaque-2 mutation made the endosperm unpleasant taste, chalky, lighter and soft (starch granules loosely packed) resulting damaged kernel while harvesting, increased susceptibility to pest and diseases, inferior for food processing and in general reduced cob weight and lower yield due to reduced dry matter accumulation. For many years, this became the major hindrance in genetic improvement for higher productivity with enriched nutritional quality. Subsequently, the opaque-2 mutation is reported to be associated with numerous modifiers which together behave as polygenic trait for kernel virtuousness. Later, concerted effort of Surinder K. Vasal and Evangelina Villegas (CIMMYT) made it possible to improve kernel hardness and grain yield by combining the opaque-2 and its complex genetic modifier systems using modified backcrossing and recurrent selection. This gave birth to the quality protein maize (QPM).

There are several mutants that alter the amino acid profile of maize endosperm protein. These include opaque-2(o2), floury-2 (fl-2), Mucronate (Mc) and Defective endosperm B30 (DEB30). The opaque mutants are recessive (o1, o2, o5, o9-11, o13, 016, o17), the floury mutations are semi-dominant (fl-1, fl-2 and fl-3) where as 'Mucronate' and 'Defective endosperm' are dominant mutations. The opaque mutations affect the regulatory network (Mertz et al. 1964, Nelson et al. 1965, Krivanek et al. 2007) whereas floury, Mucronate and defective endosperm affects the amino acid profile of storage proteins (Gibbon \& Larkin 2005). Similar to opaque 2; opaque-16 mutant allele is also reported to increase lysine and tryptophan content in the endosperm. Recently, a transposable element ' $r b g$ ' is reported to induce differential expression of opaque-2 mutant gene in two opaque 2 NILs derived from the same inbred line (Chen et al. 2014).

The molecular evolution of the opaque-2 gene was investigated by Henry et al. (2005). Sequencing of most of the coding regions and parts of non-coding sequences of the 02 gene in a set of cultivated and teosinte (wild progenitor of cultivated maize) accessions revealed 5.4\% polymorphic sites and 72 insertions/deletions, located mostly in noncoding regions. Cultivated accessions retained about $70 \%$ of the diversity observed in teosintes. Besides, the molecular diversity in the 02 transcriptional activator was reported to be quite high compared to that of other transcription factors in maize (Henry et al. 2005).

In fact, opaque-2 (o2) is a natural recessive mutation in the transcriptional activator conditioning negative expression of zein protein (down regulation). This led to nearly double the lysine and tryptophan content in maize endosperm due to a decrease in the synthesis of zein proteins and increase in the other seed protein bound lysine and tryptophan (Henry et al. 2005). The 02 gene has a large effect on lysine and protein content while minor on oil content (Lou et al. 2005). It seems that developing maize seeds possess compensatory mechanisms that sense protein content when zein synthesis is interrupted, leading to translation of other mRNAs instead of zein mRNAs. Combining deletion mutagenesis with current methods in genome and transcriptome profiling can make it possible to reveal alteration in amino acid composition (Holding 2014). RNA interference based down regulation of $22 \mathrm{kD}$ RNAi lines is reported to cause opaque phenotype more profoundly as compared to $19 \mathrm{kD}$ component. This is probably due to the greater interaction of $22 \mathrm{KDa}$ components with $\beta$ and $\gamma$-zeins resulting in a disruption in protein body formation which causes the opaque phenotype (Segal et al. 2003, Huang et al. 2004). Besides, Zhang et al. (2010) were able to trace the inheritance of opaque-16 mutant allele which also linked to the elevated synthesis of lysine and tryptophan content. Transfer of this high lysine gene $\left(\mathrm{o}_{16}\right)$ into opaque -2 genetic background can further enhance the lysine content.

The details of proteome modulation that operates to alter amino acid composition are not clear. A microarray analysis of 1400 maize genes revealed that the 60 genes up-regulated more than three times in the mutant are related to stress responses, molecular chaperones and protein turn over (Prioul et al. 2008). Interestingly, among 
the 66 down-regulated genes, many genes are involved in carbon, carbohydrate metabolism and branched chain amino acids (Hunter et al. 2002). Studies revealed that LKR/SDH (lysine-ketoglutarate reductase/saccharopine dehydrogenase) -the first enzyme of lysine catabolism is strongly depressed in 02 mutants as compared to wild type (Brochetto-Braga et al. 1992, Azevedo et al. 2003). During the process of evolution, segmental duplication in the progenitor genome of maize (Teosinte) is reported to result in diverged copies of the regulatory opaque-2 gene (Xu \& Messing 2008). Recently, a 15.26kb duplication segment (qy27) at the $27-\mathrm{kDa} \gamma$-zein locus is reported to be a major modifier QTL which confers enhanced expression of this protein and leads to endosperm hardness (Liu et al. 2016). They mapped the said major QTL within a narrow interval of 100kb between the marker 0916-2 and Ch7-120.35 through fine mapping. Proteomic analysis using SDS-PAGE indicated that o2 introgression decreased the accumulation of various zein proteins except for 27-kDa $\gamma$-zein and also affected other endosperm proteins related to amino acid biosynthesis, starch-protein balance, stress response and signal transduction (Zhang et al. 2015, Zhou et al. 2016).

Pleiotropic effects of opaque-2 gene has been recognized. Expression of the 02 gene environment labile and also depends on background polygenes which accounts for appreciable variation in amino acid composition and opaque phenotypes (Lou et al. 2005). However, In addition to alteration in amino acid composition, it affects starch organization making the kernel softer, opaque in appearance and unpleasant taste. A set of modifier genes (QTLs) in the opaque -2 genetic background are known to impove hard and vitreous kernels (Bjarnason et al. 1976, Ortega \& Bates 1983, Burnett \& Larkins 1999). Inheritance of o2 modifiers is complex (Vasal et al. 1980). Two major QTLs associated with endosperm modification have been identified. Vasal et al. (1980) combined the opaque-2 allele with QTLs for genetic modifiers and produced elite germplasm with the hard kernel and much higher quantity of lysine and tryptophan. The modified opaque -2 mutants are reported to bring about reduced levels of $22 \mathrm{KDa} \alpha$-zeins and 2-3 times higher levels of $27 \mathrm{KDa}$-zeins (Geetha et al. 1991) along with increased hardness of the kernel (Moro et al. 1995). Besides, Krivanek et al. (2007) reported the involvement of a series of amino acid modifier genes for improvement of lysine and tryptophan. The genetics of amino acid modifiers is not well understood. Nevertheless, accumulation of favourable amino acid modifiers in o2 genetic background was accomplished by recombination breeding, and subsequently, several QPM pools were generated to provide genetic stocks for QPM breeding programmes (Sofi et al. 2009).

The opaque-2 gene was identified near to defective endosperm gene 'DEB 30' in the short arm of Chromosome 7 (Holding \& Larkins 2008, Holding et al. 2008, Sofi et al. 2009); while, following RFLP analysis in an $\mathrm{F}_{2}$ population, two major QTLs associated with endosperm modification have been identified near the centromere and telomere, respectively, on the long arm of the same chromosome (Lopes et al. 1995). A large number of reports followed wherein varying degrees of endosperm modifications were observed (Paez et al. 1969). The mechanism underlying the change of grain structure from chalky to vitreous in modified opaque-2 mutants (mo2) is yet to be elucidated. But, breeders can undertake selection approach to accumulate QTLs to regulate this tightly controlled program (Dudley \& Lambert 2004). Vasal et al. (1980) combined the opaque-2 allele with QTLs for genetic modifiers and produced modified version of QPM germplasm with the hard kernel and much higher quantity of lysine and tryptophan.

A number of researchers revealed polymorphic molecular profiles of QPM lines using RAPD (Nkongolo et al. 2011, Hemavathy 2015), ISSR (Nkongolo et al. 2011, Lenka et al. 2015), SSR (Bantte \& Prasanna 2003) and SNP (Semagn et al. 2012) markers. Bantte \& Prasanna (2003) identified a few SSR markers e.g., bnlg 105, bnlg 125, bnlg 439, phi 037 and dupssr 34 with high polymorphic information content to differentiate QPM lines. But, none of these proved efficient to detect polymorphism between QPM and Normal maize inbreds. However, Identification of molecular markers that co-inherit with the opaque 2 phenotype is a crucial step for their use in marker assisted breeding. CIMMYT designed o2-gene specific SSR primers viz, phi 057, phi 112 and umc 1066 which are located as internal repetitive elements within opaque-2 gene on the short arm of chromosome 7(www.agron.missouri.edu). Among these phi 057 and Umc 1066 are reported to be co-dominant while phi 112 is a dominant marker (Magulama \& Sales 2009). Allelic polymorphism among QPM and normal maize inbreds was surveyed by several workers (Babu et al. 2005, Jompuk et al. 2006, Magulama \& Sales 2009, Gupta et al. 2013) using these gene specific SSR primers and confirmed the codominant status of phi 057 and umc 1066. Phi 057 is reported to reveal a very good polymorphism with QPM donors showing a 169bp band and normal maize inbreds with a 159bp fragment (Magulama \& Sales 2009). Bantte \& Prasanna (2003) detected 30 unique SSR alleles to differentiate QPM inbreds. They also identified the SSR primer phi 057 to detect QPM 
inbreds carrying opaque 2 mutation. Kata et al. (1994) used RFLP technique using Hind III digestion of genomic DNA and opaque-2 locus specific cDNA probe to detect o2/o2, o2/o2, and o2/o2 genotypes of individual plants in breeding populations. Besides, Zhang et al. (2010) reported the use of molecular marker umc1141 to trace the inheritance of the erstwhile mentioned opaque-16 mutant allele that led to the elevated synthesis of lysine and tryptophan content.

\section{BREEDING FOR QUALITY PROTEIN MAIZE (QPM)}

Maize is a cross pollinated crop. The major breeding approach for increasing productivity is production of hybrids using heterosis breeding. The success of this method depends on development and identification of suitable inbred lines using an appropriate mating design; and selection of most promising heterotic normal maize hybrid. Now, QPM hybrids have been developed and tested for varying climatic and growing conditions. QPM varieties are grown on roughly 9 million acres worldwide following their spread from Mexico to throughout Latin America and to Africa, Europe, and Asia (Kataki \& Babu 2003). For the production of QPM hybrid, the ultimate aim is to combine the advantage of heterosis along with amelioration of amino acid composition using QPM donors. To achieve this, conversion of both parental non-QPM inbreds to QPM status is the first step to develop a heterotic QPM hybrid. A number of reliable QPM donors (composite K; Ver 181Ant gp venezula-1, Thai composite, PD 9MS6 and composite-1) are now available at CIMMYT. These QPM donor stocks have been developed through intra-population selection for genetic modifiers in opaque-2 backgrounds and are currently being used for large scale conversion of non-QPM inbreds to their QPM version. Subsequently, combining ability studies in QPM germplasm have been conducted and published (Vasal et al. 1993a, 1993b) so as to assist QPM hybrid development. Vivek et al. (2008) reported tryptophan content more than $0.60 \%$ and lysine content more than $2.6 \%$ in a set of CIMMYT QPM inbreds. Besides, Ortega \& Villegas (1988) reported on an average $0.8 \%$ tryptophan and 3.1\% lysine content among a set of QPM inbreds as against $0.4 \%$ and $1.6 \%$ respectively in normal maize lines. The inbred lines e.g., CML 176 and CML 186 are reported to be potential QPM donors (Manna et al. 2005, Danson et al. 2006) for introgression of o2 allele to non-QPM maize.

The opaque-2 allele is recessive (Vasal et al. 1993a, b) in nature, but the endosperm modifiers follow polygenic inheritance. At CIMMYT, a conservative approach is adapted to develop modified opaque 2 (mo2) genotypes to strike a balance between proteins levels and grain quality and competitive yield levels. However, molecular marker based screening for QPM status coupled with phenotypic selection to improve endosperm characteristics seems to be an appropriate strategy for the development of QPM introgression lines. The erstwhile mentioned gene-specific co-dominant markers phi 057 (Manna et al. 2005, Danson et al. 2006, Magulama \& Sales 2009) and umc 1066 (Singh \& Ram 2014, Gupta et al. 2009, Gupta et al. 2013) are worthwhile to trace the opaque-2(o2) allele in conversion programme. Distinct polymorphism revealed by both the primers can discriminate the QPM donors from respective non-QPM recurrent parents and also between homozygous (0202) and heterozygous (0202) opaque-2 back cross progeny. This paves the way for rejection of non target $\mathrm{BC}$ progenies (dominant homozygous) resulting short cutting the breeding cycle (eliminates the need to grow $\mathrm{F}_{2}$ ) and substantial savings of labour and material resources for amino acid estimation (Tanksley et al. 1989, Frisch et al.1999, Gupta et al. 2013). This made it possible to bred a QPM hybrid in less than half the time required in conventional breeding. Besides, foreground selection for opaque- 2 combined with phenotypic selection for recipient parent at early back cross generations can bring about rapid recovery of recurrent parent genotype. The introgression lines developed using marker assisted back cross breeding may serve as important breeding material for the development of QPM hybrids.

Two Brazian QPM varieties e.g., BR 451 and BR 473 developed by the Breeding Program of the National Maize and Sorghum Research Center (CNPMS - EMBRAPA) were released in 1988 and 1994 respectively for commercial cultivation. The former has been successfully used as a substitute for wheat due to its white color; while the yellow colour kernel of the later resembles normal maize resulting consumers acceptance as a substitute of normal maize. A mixture of wheat flour with that of BR 451 in a suitable proportion was reported ideal for industrial production of bread, cookies, and pasta (Peixoto et al. 1989). Besides, a double cross QPM hybrid was released in Brazil during 1997. Thereafter, a QPM hybrid Zhongdan 9407 was soon released in China. India has also released Shakti-1 in 1998 and is deeply involved in testing hybrids from CIMMYT. In India, Vivek QPM-9: a hybrid of two QPM introgression lines was released in 2008 (Gupta et al. 2009, Gupta et al. 2013) for commercial cultivation. CML 180 and CML 170 were selected as QPM donors for introgression of 
opaque-2 allele into the parental normal maize inbreds CM 212 and CM 145 through marker assisted backcross breeding. The said QPM hybrid, showed 41\% increase in tryptophan and 30\% increase in lysine over the original hybrid. However, the grain yield of the improved hybrid was on par with the original hybrid. Soon after, many countries participated in QPM network. The Republic of South Africa had earlier released hybrids HL-1, HL-2, and has recently released HL8 which has hard endosperm, good yield potential, and tolerance to diseases. In the similar line of work, marker-assisted backcross breeding (MABB) has been also used to develop maize genotypes for reduced anti-nutritional factors (Naidoo et al. 2012). Muthusamy et al. (2014) developed BCarotene rich maize hybrids through marker-assisted introgression of $\beta$-carotene hydroxylase allele. Chander et al. (2008) identified a major locus (y1) for carotenoid content using gene targeted molecular marker (Y1ssr).

\section{CONCLUSION}

Quality protein maize has a far-reaching impact on nutritional security with the discovery of opaque-2 mutation. Such a natural recessive mutation led to selective down-regulation of specific zein genes resulting alteration in amino acid composition and opaque phenotype of endosperm. Modified marker assisted back cross breeding made it possible to develop QPM versions of normal maize inbreds with desirable endosperm characteristics and seed yield. These QPM introgression lines may be combined to develop QPM hybrids.

\section{ACKNOWLEDGEMENT}

We sincerely acknowledge and thank all researchers for their valuable contributions included in the text as references.

\section{REFERENCES}

Azevedo RA, Damerval C, Landry J, Lea PJ, Bellato CM, Meinhardt LW, Guilloux ML, Delhaye S, Toro AA, Gaziola SA \& Berdejo BD (2003) Regulation of maize lysine metabolism and endosperm protein synthesis by opaque and floury mutations. European Journal of Biochemistry 270: 4898-4908.

Bantte K \& Prasanna B (2003) Simple sequence repeat polymorphism in Quality Protein Maize (QPM) lines. Euphytica 129(3): 337-344.

Babu R, Nair SK, Kumar A, Venkatesh S, Sekhar JC, Singh NN, Srinivasan G \& Gupta HS (2005) Two generation marker aided backcrossing for rapid conversion of normal maize lines to quality protein maize (QPM). Theoretical and Applied Genetics 111: 888-897.

Bjarnason M, Polmer WG \& Klein D (1976) Inheritance of modified endosperm structure and lysine content in opaque-2 maize. I. Modified endosperm structure. Cereal Research and Communication 4: 401-410.

Brochetto-Braga MR, Leite A \& Arruda P (1992) Partial purification and characterization of lysineketoglutarate reductase in normal and opaque-2 maize endosperms. Plant Physiology 98: 1139-1147.

Burnett RJ \& Larkins BA (1999) opaque-2 modifiers alter transcription of the 27-kDa gamma-zein genes in maize. Molecular and General Genetics 261: 908-916.

Chander S, Guo QY, Yang HX, Zhang J \& Lu XQ (2008) Using molecular markers to identify two major loci controlling carotenoid contents in maize grains. Theoretical Applied Genetics 116: 223-233.

Chen Y, Zhou Z, Zhao G, Li X, Song L, Yan N, Weng J, Hao Z, Zhang D, Li M \& Zhang S (2014) Transposable element rbg induces the differential expression of opaque-2 mutant gene in two maize 02 NILs derived from the same inbred line. PLoS One 9(1): e85159.

Coleman C \& Larkins BA (1999) The prolamins of maize. In: Shewry PR \& Casey R (Eds) Seed proteins. Dordrecht. Kluwer Academic Publishers, pp. 109-139.

Danson J, Mbogori M, Kimani M, Lagat M, Kuria A \& Diallo A (2006) Marker assisted introgression of opaque-2 gene into herbicide tolerant elite maize inbred lines. African Journal of Biotechnology 5: 24172422.

Dudley JW \& Lambert RJ (2004) 100 Generations of selection for oil and protein in corn. Plant Breeding Review 24: 79-110.

Dudley JW \& Lambert RJ (1969) Genetic variability after 65 generations of selection in Illinois high oil, low oil, high protein and low protein strains of Zea mays L. Crop Science 9: 179-181.

Esen A \& Stetler DA (1992) lmmuno-cytochemical location of y-zein in the protein bodies of maize endosperm. American Journal of Botany 79: 243-248. 
Frisch M, Bohn M \& Melchinger AE (1999) Comparison of selection strategies for marker assisted backcrossing of a gene. Crop Science 39: 1295-1301.

Geetha K, Lending C, Lopes M, Wallace J \& Larkins B (1991) Opaque-2 modifiers increase a-zein synthesis and alter its spatial distribution in maize endosperm. Plant Cell 3: 1207-1219.

Gibbon B \& Larkin B (2005) Molecular genetic approaches to developing quality protein maize. Trends in Genetics 21: 227-233.

Gupta HS, Agrawal PK, Mahajan V, Bisht GS, Kumar A, Verma P, Srivastava A, Saha S, Babu R, Pant MC \& Mani VP (2009) Quality protein maize for nutritional security: Rapid development of short duration hybrids through molecular marker assisted breeding. Current Science 96: 230-237.

Gupta HS, Babu R, Agrawal PK, Mahajan V, Hossain F \& Thirunavukkarasu N (2013) Accelerated development of quality protein maize hybrid through marker assisted introgression of opaque -2 allele. Plant Breeding 132(1): 77-82.

Hemavathy AT (2015) Molecular marker based genetic diversity in quality protein maize. International Journal of Recent Scientific Research 6(5): 3848-3851.

Henry AM, Manicacci D, Falque M \& Damerval C (2005) Molecular evolution of the opaque-2 gene in Zea mays L. Journal of Molecular Evolution 61(4): 551-558.

Holding DR \& Larkins BA (2008) Genetic modification of seed storage proteins. In: Lewis NG (Ed. In chief) Advances in plant biochemistry and molecular biology Vol.1: Bohnert HJ \& Nguyen HT (Eds) Bioengineering and molecular biology of plant pathways. Elsevier Publishers, Oxford, UK, pp. 107-133.

Holding DR, Hunter BG, Chung T, Gibbon BC, Ford CF, Bharti AK, Messing J, Hamaker BR \& Larkins BA (2008) Genetic analysis of opaque-2 modifier loci in quality protein maize. Theoretical Applied Genetics 117(2): 157-170.

Holding DR (2014) Recent advances in the study of prolamin storage protein organization and function. Frontier of Plant Science 20(5): 276.

Huang S, Adams W, Zhou Q, Malloy K, Voyles D, Anthony J, Kriz A \& Luethy M (2004) Improving nutritional quality of maize proteins by expressing sense and antisense genes. Journal of Agriculture and Food Chemistry 52: 1958-1964.

Hunter BG, Beatty MK, Singletary GW, Hamaker BR, Dilkes BP, Larkins BA \& Jung R (2002) Maize opaque endosperm mutations create extensive changes in patterns of gene expression. Plant Cell 14: 2591-2612.

Jompuk P, Wongyai W, Jampatong C \& Apisitvanich S (2006) Detection of quality protein maize (QPM) using simple sequence repeat (SSR) markers and analysis of tryptophan content. Kasetsart Journal (Natural Science) 40: 768-774.

Kata SR, Taylor BH, Bockholt AJ \& Smith JD (1994) Identification of opaque 2 genotypes in segregating populations of quality protein maize by analysis of restriction fragment length polymorphisms. Theoretical and Applied Genetics 89(4): 407-412.

Kataki PK \& Babu SC (2003) Food systems for improved human nutrition: linking agriculture, nutrition, and productivity. Haworth Press, pp. 193. [ISBN 1-56022-103-8]

Krivanek A, Groote H, Gunaratna N, Diallo A \& Freisen D (2007) Breeding and disseminating quality protein maize for Africa. African Journal of Biotechnology 6: 312-324.

Larkins BA, Lending CR \& Wallace JC (1993) Modification of maize-seed-protein quality. American Journal of Clinical Nutrition 58(2 Suppl.): 264S-269S.

Leite A, Neto GC, Vettore AL, Yunes JA \& Arruda P (1999) The prolamins of sorghum, Coix and millets. In: Shewry PR \& Casey R (Eds) Seed proteins. Dordrecht. Kluwer Academic Publishers, pp. 141-157.

Lending CR, Chesnut RS, Shaw KL \& Larkins BA (1992) Synthesis of zeins and their potential for amino acid modification. In: Shewry PR \& Gutteridge S (Eds) Plant Protein Engineering. Cambridge. Cambridge University Press, pp. 209-218.

Lending CR \& Larkins BA (1989) Changes in the zein composition of protein bodies during maize endosperm development. Plant Cell 1: 10-11.

Lenka D, Tripathy SK, Ramesh K, Behera M \& Ranjan R (2015) Assessment of genetic diversity in quality protein maize inbreds using ISSR markers. Journal of Environmental Biology 36(4): 985-992.

Liu H, Shi J, Sun C, Gong H, Fan X, Qiu F, Huang X, Feng Q, Zheng X, Yuan N, Li C, Zhang Z, Deng Y, Wang J, Pan G, Han B, Lai J \& Wu Y (2016) Gene duplication confers enhanced expression of 27-kDa $\gamma$ - 
zein for endosperm modification in quality protein maize. Proceedings of National Academy of Science 113(18): 4964-4969.

Lou X, Zhu J, Zhang Q, Zang R, Chen Y, Yu Z \& Zhao Y (2005) Genetic control of the opaque-2 gene and background polygenes over some kernel traits in maize (Zea mays L.). Genetica 124(2-3): 291-300.

Lopes MA, Takasaki K, Bostwick DE, Helentjaris T \& Larkins BA (1995) Identification of two opaque2 modifier loci in quality protein maize. Molecular and General Genetics 247: 603.

Magulama E \& Sales EK (2009) Marker assisted introgression of opaque-2 gene into elite maize inbred lines. Academia.Education, USM R \& D 17(2): 131-135.

Manna R, Okello DK, Imanywoha J, Pixley K \& Edema R (2005) Enhancing introgression of the opaque-2 trait into elite maize lines using simple sequence repeats. African Crop Science Journal 13: 215-226.

Mertz ET, Bates LS \& Nelson OE (1964) Mutant gene that changes protein composition and increases lysine content of maize endosperm. Science 145: 279.

Moro GL, lopes MA, Habben JE, Hamaker BR \& Larkins BA (1995) Phenotypic effects of modifier genes in normal maize endosperm. Cereal Chemistry 72: 94-99.

Muthusamy V, Hossain F, Thirunavukkarasu N, Choudhary M, Saha S \& Bhat JS (2014) Development of $\beta$ carotene rich Mmaize hybrids through marker-assisted introgression of $\beta$-carotene hydroxylase allele. PLoS One 9(12): e113583.

Naidoo R, Tongoona P, Derera J, Laing MD \& Watson GMF (2012) Combining ability of low phytic acid (lpa1-1) and quality protein maize (QPM) lines for seed germination and vigour under stress and non-stress conditions. Euphytica 185(3): 529-541.

Nelson OE, Mertz ET \& Bates LS (1965) Second mutant gene affecting the amino acid pattern of maize endosperm proteins, Science 150: 1469.

Nkongolo KK, Mbuya K, Mehes-Smith M \& Kalonji-Mbuyi A (2011) Molecular analysis of quality protein (QPM) and normal maize varieties from the DR-Congo breeding program. African Journal of Biotechnology 10(65): 14293-14301.

Ortega EI \& Bates LS (1983) Biochemical and agronomic studies of two modified hard-endosperm opaque-2 mutants. Cereal Chemistry 60: 107-1110.

Ortega EI \& Villegas E (1988) Nutritionally improved maize, Chapter-Nutritionally improved maize : Report of an adhoc panel of the advisory committee on technology innovation. Protein Quality Laboratory, CIMMYT Ortega EI and Villegas E Open Book, The National Academic Press, pp. 32.

Paez A, Helm J \& Zuber S (1969) Lysine content of opaque-2 kernels having different phenotypes. Crop Science 9: 251-252.

Peixoto MJVV, Parentoni SN, Gama EEG, Magnavaca R, Paiva E \& Rego MM (1989) Perspectiva de utilização de milhos de alta qualidade protéica no Brasil. Informe Agropecuário 14(165): 23-34.

Prioul JL, Méchin V \& Damerval C (2008) Molecular and biochemical mechanisms in maize endosperm development: The role of pyruvate-Pi-dikinase and opaque-2 in the control of $\mathrm{C} / \mathrm{N}$ ratio. CR Biologies 331: 772-779.

Singh R \& Ram L (2014) DNA aided introgression of opaque-2 allele for development of quality protein maize. International Journal of Science \& Research 3(2): 3006-3011.

Segal G, Song R \& Messing J (2003) A new opaque variant of maize by a single dominant RNA-interferenceinducing transgene. Genetics 165: 387-397.

Semagn K, Magorokosho C, Vivek BS, Makumbi D, Beyene Y, Mugo S, Prasanna BM \& Warburton ML (2012) Molecular characterization of diverse CIMMYT maize inbred lines from eastern and southern Africa using single nucleotide polymorphic markers. BMC Genomics 13: 113.

Sofi PA, Wani SA, Rather AG \& Wani SH (2009) Quality protein maize (QPM): Genetic manipulation for the nutritional fortification of maize. Journal of Plant Breeding \& Crop Science 1(6): 244-253.

Tanksley SD, Young ND, Paterson AH \& Bonierbale MW (1989) RFLP mapping in plant breeding: New tools for an old science. Biotechnology 7: 257-264.

Vasal SK, Villegas E, Bjarnason M, Gelaw B \& Goertz P (1980) Genetic modifiers and breeding strategies in developing hard endosperm opaque-2 materials. In: Pollmer WG \& Phillips RH (Eds) Improvement of quality traits of maize for grain and silage use. Nijhoff, London, pp. 37-43. 
Vasal SK, Srinivasan G, Pandey S, Ganzalez F, Crossa J \& Beck DF (1993a) Heterosis and combinign abiity of CIMMYT's Quality protein maize germplasm. I. lowland tropical. Crop Science 33: 46-51.

Vasal SK, Srinwasan G, Gonzalez C, Beck D \& Crossa J (1993b) Heterosis and combining ability of CIMMYT's quality protein maize germplasm. II. Sub-tropical. Crop Science 33: 51-57.

Vivek BS, Krivanek AF, Palacios-Rojas N, Twumasi-Afriyie S \& Diallo AO (2008) Breeding quality protein maize (QPM): Protocols for developing QPM cultivars. Mexico, D.F., CIMMYT, pp. 5.

Xu J.H. \& Messing J (2008) Diverged copies of the seed regulatory opaque-2 gene by a segmental duplication in the progenitor genome of rice sorghum and maize. Molecular Plant 1(5): 760-769.

Zhang W, Yang W, Chen Z, Wang M, Yang L \& Cai Y (2010) Molecular marker-assisted selection for o2 introgression lines with $\mathrm{o}_{16}$ gene in corn. Acta Agronomica Sinica 36(8): 1302-1309.

Zhang Z, Yang J \& Wu Y (2015) Transcriptional regulation of zein gene expression in maize through the additive and synergistic action of opaque-2, prolamine-box Binding factor, and 02 heterodimerizing proteins. The Plant Cell 21: 1-11.

Zhou Z, Song L, Zhang X, Li X, Yan N, Xia R, Zhu H, Weng J, Hao Z, Zhang D, Yong H, Li M \& Zhang S (2016) Introgression of opaque-2 into waxy maize causes extensive biochemical and proteomic changes in endosperm. PLoS One 11(7): e0158971. 